\title{
Propranolol potentiates the anti-angiogenic effects and anti- tumor efficacy of chemotherapy agents: implication in breast cancer treatment
}

\author{
Eddy Pasquier ${ }^{1,5}$, Joseph Ciccolini2, Manon Carre ${ }^{3}$, Sarah Giacometti ${ }^{2}$, Raphaelle \\ Fanciullino ${ }^{2}$, Charlotte Pouchy ${ }^{1, *}{ }^{,}$Marie-Pierre Montero ${ }^{3}$, Cindy Serdjebi ${ }^{2}$, Maria \\ Kavallaris ${ }^{1}$ and Nicolas André Ka, $^{3,4}$ \\ ${ }^{1}$ Children's Cancer Institute Australia, Lowy Cancer Research Centre, UNSW, Randwick, NSW, Australia \\ 2 Pharmacokinetics Unit, UMR-MD3, Aix-Marseille Univ, Marseille, France \\ ${ }^{3}$ INSERM UMR 911, Centre de Recherche en Oncologie biologique et en Oncopharmacologie, Aix-Marseille Univ, Marseille \\ ${ }^{4}$ Hematology \& Pediatric Oncology Department, La Timone University Hospital of Marseille, France \\ ${ }^{5}$ Metronomics Global Health Initiative, Marseille, France \\ ‡Current Address: Université Pierre et Marie Curie - Univ Paris 6, CNRS UMR 7211, INSERM U959, Paris, France \\ Correspondence to: Eddy Pasquier, PhD, email: epasquier@ccia.unsw.edu.au
}

Nicolas André, MD,PhD, email: nicolas.andre@ap-hm.fr

Keywords: breast cancer, angiogenesis, propranolol, beta-adrenergic receptor antagonist, chemotherapy, combination therapy Received: October 13,2011, Accepted: October 14, 2011, Published: October 17, 2011

Copyright: @ Pasquier et al. This is an open-access article distributed under the terms of the Creative Commons Attribution License, which permits unrestricted use, distribution, and reproduction in any medium, provided the original author and source are credited.

ABSTRACT:

Recent clinical evidence revealed that the use of beta-blockers such as propranolol, prior to diagnosis or concurrently with chemotherapy, could increase relapse-free and overall survival in breast cancer patients. We therefore hypothesized that propranolol may be able to increase the efficacy of chemotherapy either through direct effects on cancer cells or via anti-angiogenic mechanisms. In vitro proliferation assay showed that propranolol (from 50-100 $\mu \mathrm{M}$ ) induces dose-dependent anti-proliferative effects in a panel of 9 human cancer and "normal" cell lines. Matrigel assays revealed that propranolol displays potent anti-angiogenic properties at non-toxic concentrations $(<50 \mu \mathrm{M})$ but exert no vascular-disrupting activity. Combining chemotherapeutic drugs, such as 5-fluorouracil (5-FU) or paclitaxel, with propranolol at the lowest effective concentration resulted in synergistic, additive or antagonistic effects on cell proliferation in vitro depending on the cell type and the dose of chemotherapy used. Interestingly, breast cancer and vascular endothelial cells were among the most responsive to these combinations. Furthermore, Matrigel assays indicated that low concentrations of propranolol $(10-50 \mu \mathrm{M})$ potentiated the anti-angiogenic effects of 5-FU and paclitaxel. Using an orthotopic xenograft model of triple-negative breast cancer, based on injection of luciferase-expressing MDA-MB-231 cells in the mammary fat pad of nude mice, we showed that propranolol, when used alone, induced only transient anti-tumor effects, if at all, and did not increase median survival. However, the combination of propranolol with chemotherapy resulted in more profound and sustained anti-tumor effects and significantly increased the survival benefits induced by chemotherapy alone $(+19 \%$ and $+79 \%$ in median survival for the combination as compared with 5-FU alone and paclitaxel alone, respectively; $\mathrm{p}<0.05$ ). Collectively our results show that propranolol can potentiate the anti-angiogenic effects and antitumor efficacy of chemotherapy. The current study, together with retrospective clinical data, strongly suggests that the use of propranolol concurrently with chemotherapy may improve the outcome of breast cancer patients, thus providing a strong rationale for the evaluation of this drug combination in prospective clinical studies. 


\section{INTRODUCTION}

The costs associated with drug development are rising so dramatically that cheaper, faster and more effective strategies to identify new compounds and implement them successfully in the clinic are desperately needed [1]. In the current financial and economical context, drug repositioning, which consists of using already approved drugs for new medical indications, is gaining increasing interest as an alternative strategy for drug development [2-4]. By using drugs with well-known toxicity and pharmacokinetics profiles, this strategy can remove several years, substantial risks and costs from the pathway to the clinic. For instance, the recent discovery of the efficacy of propranolol -a non-selective $\beta$-adrenergic receptor ( $\beta$-AR) antagonist commonly used for the treatment of hypertension- in treating severe infantile haemangioma has revolutionized the management of this pathology in 2 years $[5,6]$. Although the first evidence for a role of $\beta$-ARs in cancer progression was provided more than 20 years ago [7], the serendipitous observation of the efficacy of propranolol in treating haemangiomas has renewed interest in exploring the anti-angiogenic and anti-cancer properties of $\beta$-AR antagonists (also called $\beta$-blockers).

A number of in vitro studies have demonstrated the anti-proliferative, anti-migratory and cytotoxic properties of propranolol, particularly against lung adenocarcinoma [7, 8], colon carcinoma [9], breast carcinoma [10], nasopharyngeal carcinoma [11], ovarian cancer [12], pancreatic cancer [13-15] and gastric cancer cells [16]. Propranolol was also found to exert potent antiangiogenic effects in vitro through direct mechanisms on vascular endothelial cells $[17,18]$ and by decreasing pro-angiogenic signaling in both stromal [19] and cancer cells [11, 20-23]. Some of these promising anti-cancer properties have been confirmed in vivo using different animal models of human cancers. Propranolol was thus found to exert potent cancer preventive effects in models of chemically-induced lung and pancreatic cancers [24, 25]. Furthermore, innovative pre-clinical models of breast and ovarian cancer showed that propranolol was able to specifically inhibit stress-induced tumor growth and metastatic spread through anti-angiogenic and immunostimulatory mechanisms $[26,27]$.

Over the past 12 months, emerging clinical data have further strengthened the potential benefits of $\beta$-AR antagonists in cancer patients [28, 29]. Three retrospective clinical studies revealed that the use of $\beta$-AR antagonists, prior to diagnosis and/or concomitantly with chemotherapy, was associated with increased survival and/or decreased metastatic spread and incidence of tumor recurrence in breast cancer patients [30-32]. Different molecular mechanisms have been proposed to explain such benefits of $\beta$-AR antagonists in breast cancer patients [28, 29 ], focusing on the anti-metastatic properties of $\beta$-AR antagonists alone. Here, we hypothesized for the first time that $\beta$-AR antagonists, and propranolol in particular, may be able to increase the efficacy of chemotherapy by potentiating the anti-proliferative and/or anti-angiogenic effects of chemotherapeutic drugs. We thus proposed to investigate the combination of propranolol and chemotherapy on cell proliferation and angiogenesis in vitro and on tumor growth inhibition and survival in vivo using an orthotopic model of triple-negative breast cancer.

A

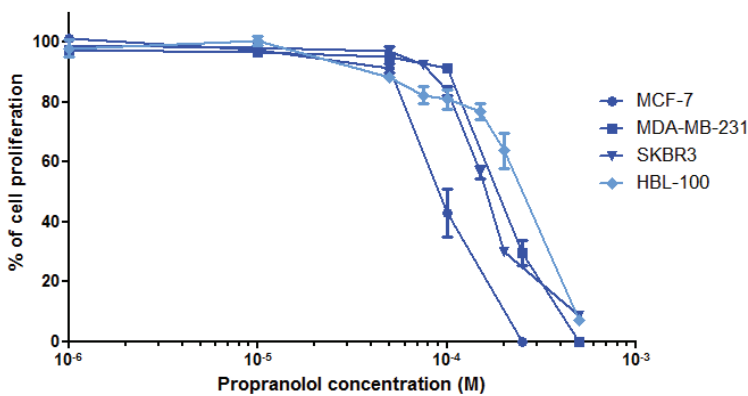

B

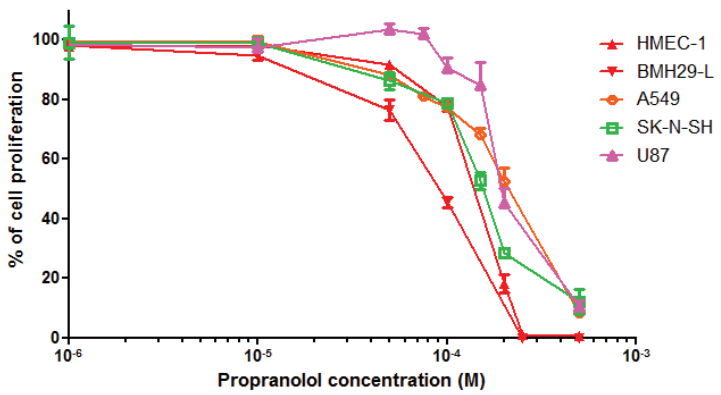

C

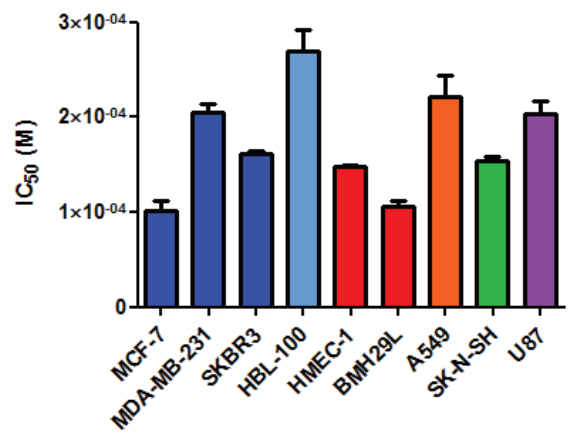

Figure 1: In vitro anti-proliferative properties of propranolol. Growth inhibition assay performed on a panel of human cell lines using Alamar Blue or MTT after $72 \mathrm{~h}$ incubation with a range of concentrations of propranolol. Three breast adenocarcinoma cell lines (MCF-7, MDA-MB-231 and SKBR3) and a breast epithelial cell line (HBL-100) were first used (A) and then a neuroblastoma (SK-N-SH), a non-small cell lung carcinoma (A549), a glioblastoma (U87) and two vascular endothelial cell lines (HMEC-1 and BMH29L) were used (B). Points, \% of cell proliferation as compared to untreated control cells, means of at least three individual experiments; bars, SE; $\log$ scale for $\mathrm{x}$ axis. C) Histogram representation of the molar concentration of propranolol required to inhibit $50 \%$ of cell proliferation after $72 \mathrm{~h}$ drug incubation $\left(\mathrm{IC}_{50}\right)$ for all tested cell lines. Columns, means of at least three individual experiments; bars, SE. 


\section{RESULTS}

\section{Propranolol exerts dose-dependent anti- proliferative and anti-angiogenic effects in vitro}

To investigate the anti-proliferative properties of propranolol in vitro a range of human cell lines were used and comprised of 6 cancer cell lines originating from breast carcinomas (MCF-7, MDA-MB-231 and SKBR3), nonsmall cell lung carcinoma (A549), neuroblastoma (SK-NSH) and glioblastoma (U87), as well as 3 "normal" cell lines including 1 breast epithelial cell line (HBL-100) and

A

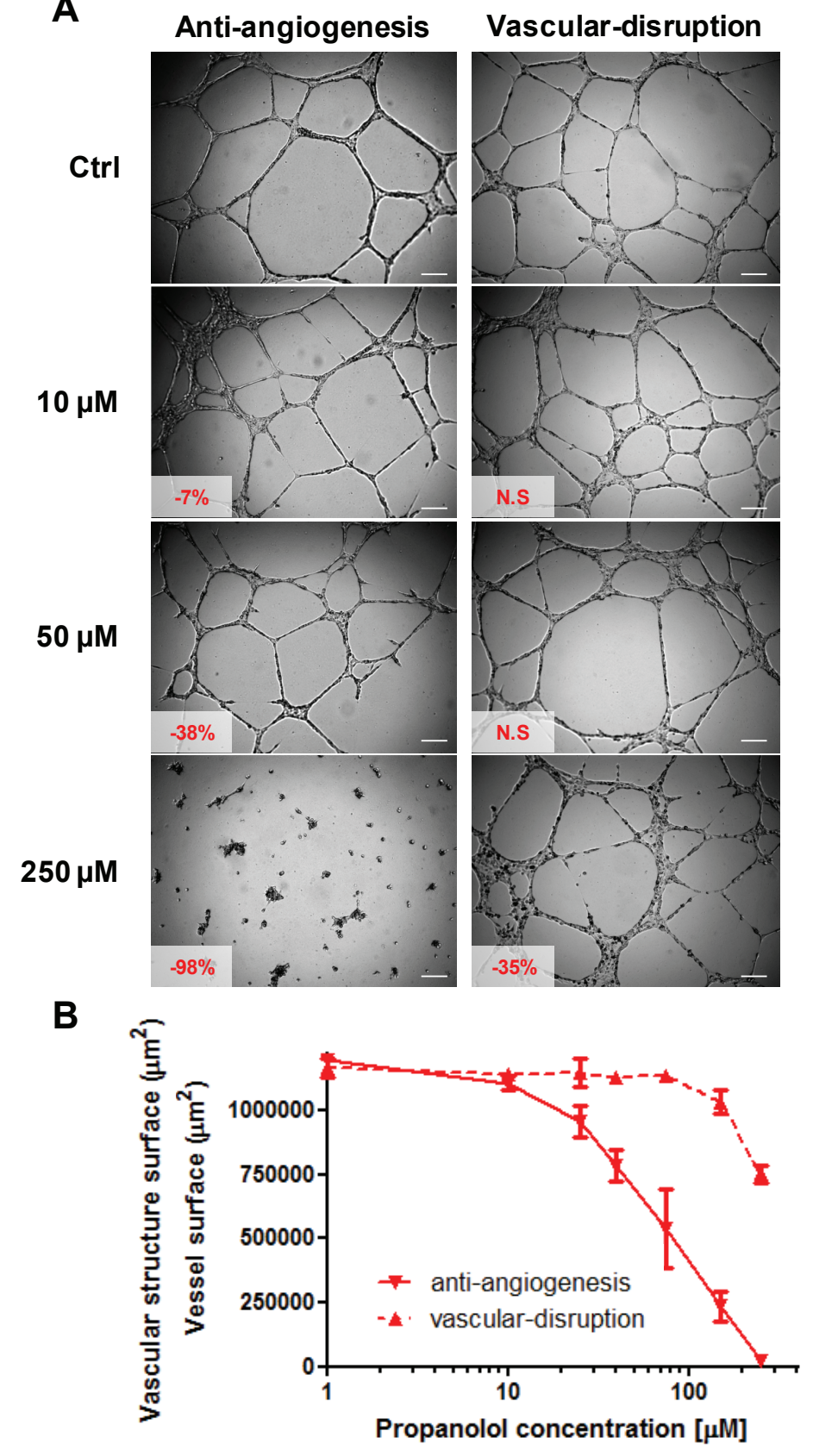

2 vascular endothelial cell lines (HMEC-1 and BMH29L). As shown in Figure 1A \& B, propranolol exerts dosedependent anti-proliferative effects against all tested cell lines. There was however a significant variability in sensitivity to propranolol across the different cell lines with $\mathrm{IC}_{50}$ values ranging from 100 to $269 \mu \mathrm{M}$ (Figure 1C). The two most sensitive cell lines were breast carcinoma cell line MCF-7 and bone marrow-derived endothelial cell line BMH29L with $\mathrm{IC}_{50}$ values of $100 \pm 11 \mu \mathrm{M}$ and $106 \pm 5 \mu \mathrm{M}$, respectively. In contrast, breast epithelial cell line HBL-100 and non-small cell lung carcinoma cell line $\mathrm{A} 549$ were the most resistant to propranolol with $\mathrm{IC}_{50}$ values of $269 \pm 22 \mu \mathrm{M}$ and $222 \pm 21 \mu \mathrm{M}$, respectively.

Two types of Matrigel $^{\mathrm{TM}}$ assays were used to examine both the anti-angiogenic and vasculardisrupting properties of propranolol in vitro. In BMH29L cells, propranolol was found to exert potent dose-dependent anti-angiogenic effects but have almost no vascular-disrupting activity (Figure 2). The formation of vascular structures was significantly inhibited after $8 \mathrm{~h}$ incubation with low concentrations of propranolol $(7,20$ and $38 \%$ inhibition at 10, 25 and $50 \mu \mathrm{M}$, respectively; $\mathrm{p}<0.01$ ) compared to control, and complete angiogenesis suppression was observed at high concentrations. In contrast, propranolol concentrations of up to $150 \mu \mathrm{M}$ induced no significant disruption of preformed vascular structures after $2 \mathrm{~h}$ drug incubation and high concentrations were required to start disrupting the vascular network (35\% disruption at $250 \mu \mathrm{M} ; \mathrm{p}<0.001)$. Similar results were obtained with HMEC-1 cells (data not shown) thus confirming that propranolol is a potent anti-angiogenic but not vascular-disrupting agent.

Figure 2: In vitro anti-angiogenic and vascular-disrupting properties of propranolol. A) Representative photographs of BMH29L cells in Matrigel ${ }^{\mathrm{TM}}$ assays. For the antiangiogenesis assay (left panel), cells were treated with a range of propranolol concentrations $20 \mathrm{~min}$ after seeding on Matrigel ${ }^{\mathrm{TM}}$ and photographs were taken after $8 \mathrm{~h}$ drug incubation. For the vasculardisruption assay (right panel), cells were first allowed to form capillary-like structures for $6 \mathrm{~h}$ before drug treatment was initiated and photographs were taken after $2 \mathrm{~h}$ drug incubation. Vascular structures were imaged on a Zeiss Axiovert 200M using a $5 \mathrm{X}$ objective. Inset, \% of inhibition/ disruption as compared to untreated control cells (N.S = not statistically significant); Scale bar, 200 $\mu \mathrm{m}$. B) Dose-dependent anti-angiogenic (solid line) and vascular-disrupting (broken line) effects of propranolol on BMH29L cells. Points, average surface occupied by vascular structures in each view field, means of at least four individual experiments; bars, SE; log scale for $\mathrm{x}$ axis. 
Propranolol potentiates the anti-proliferative effects of chemotherapy in a cell type-specific and dose-dependent manner

Drug combination studies using growth inhibition assay were performed to determine whether propranolol can potentiate the anti-proliferative effects of chemotherapeutic drugs. The lowest effective concentration of propranolol $\left(\mathrm{IC}_{10}-\mathrm{IC}_{15}\right)$ was combined with a range of concentrations of the pyrimidine analog 5-fluorouracil (5-FU) and the microtubule-stabilizing agent paclitaxel in the panel of 9 human cell lines. After $72 \mathrm{~h}$ drug incubation, cell proliferation was measured by Alamar Blue or MTT and combination index (CI) values were calculated for all tested drug concentrations based on the Chou and Talalay method $[33,34]$. The CI theorem provides quantitative definition for additive effects $(\mathrm{CI}=$ $1)$, synergisms $(\mathrm{CI}<1)$ and antagonisms $(\mathrm{CI}>1)$ in drug combinations. The combination of propranolol with 5-FU resulted in a synergistic, additive or antagonistic interaction depending on the dose of 5-FU used and the cell type (Figure $3 \mathrm{~A}$ and Table 1). In all 3 breast cancer cell lines and HMEC-1 endothelial cells, this drug combination resulted in a slight antagonism at $1 \mu \mathrm{M} 5$-FU but the interaction became additive or synergistic with increasing concentrations of 5-FU. In BMH29L endothelial cells, the interaction between propranolol and 5-FU was synergistic at all tested concentrations. In contrast, an antagonistic effect was observed at all tested concentrations in HBL100 breast epithelial cells. Interestingly, in other types of cancer cell lines (i.e. A549, SK-N-SH and U87), the combination of propranolol and 5-FU mostly resulted in an antagonism (Table 1).

Cell type-specific and dose-dependent effects were also observed when combining propranolol and paclitaxel (Figure 3B and Table 1). In contrast with the previous drug combination, diverse effects were observed in the
A

5-fluorouracil

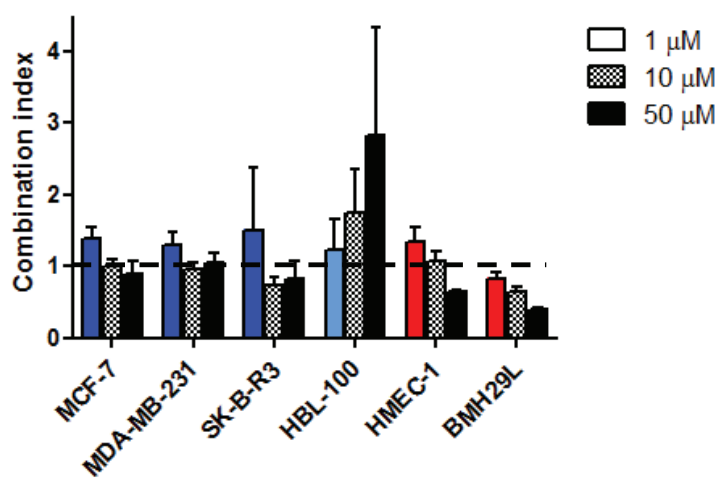

B

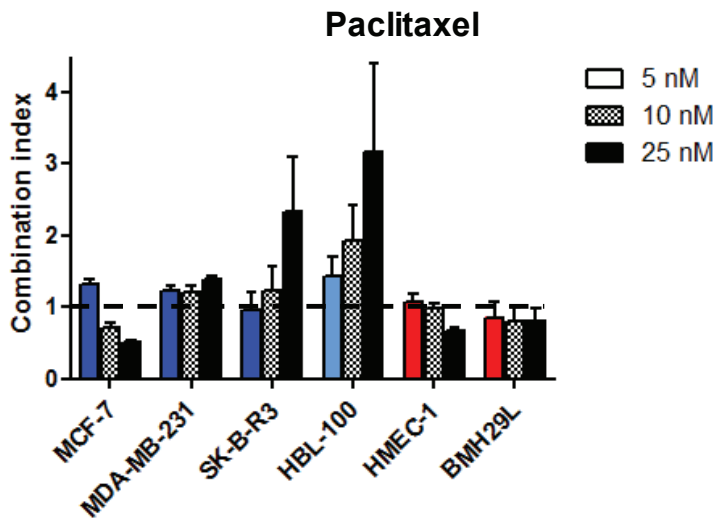

Figure 3: In vitro drug combination study of propranolol and chemotherapy on cell proliferation. Histogram representation of the combination index (CI) of propranolol in association with 5-fluorouracil (A) or paclitaxel (B) on a panel of human cell lines. Growth inhibition assays were performed using Alamar Blue or MTT after $72 \mathrm{~h}$ incubation with a range of chemotherapeutic drug concentrations in presence or absence of propranolol at the lowest effective concentration $\left(\mathrm{IC}_{15}\right)$. CI values were determined based on the Chou and Talalay method for all tested concentrations of chemotherapeutic drug. Columns, means of at least three individual experiments; bars, SE.

Table 1: Combination index of propranolol and chemotherapeutic drugs in vitro. Growth inhibition assays were performed on a panel of 9 human cell lines using Alamar Blue or MTT after $72 \mathrm{~h}$ incubation with a range of chemotherapeutic drug concentrations in presence or absence of propranolol at the lowest effective concentration $\left(\mathrm{IC}_{15}\right)$. Combination index values $( \pm \mathrm{SE})$ were determined based on the Chou and Talalay method for all tested concentrations of chemotherapeutic drug. A color code is used to illustrate the different drug interactions: synergism (green), additivity (yellow), sub-additivity (orange) and antagonism (red).

\begin{tabular}{|l|c|c|c|c|c|c|}
\hline \multirow{2}{*}{ Cell lines } & \multicolumn{3}{|c|}{ 5-Fluorouracil } & \multicolumn{3}{c|}{ Paclitaxel } \\
\cline { 2 - 7 } & $1 \mu \mathrm{M}$ & $10 \mu \mathrm{M}$ & $50 \mu \mathrm{M}$ & $5 \mathrm{nM}$ & $10 \mathrm{nM}$ & $25 \mathrm{nM}$ \\
\hline MCF-7 & $1.38 \pm 0.16$ & $1.01 \pm 0.08$ & $0.89 \pm 0.18$ & $1.31 \pm 0.07$ & $0.71 \pm 0.07$ & $0.5 \pm 0.03$ \\
\hline MDAMB-231 & $1.3 \pm 0.18$ & $0.96 \pm 0.08$ & $1.05 \pm 0.13$ & $1.23 \pm 0.08$ & $1.21 \pm 0.1$ & $1.38 \pm 0.05$ \\
\hline SKBR3 & $1.51 \pm 0.87$ & $0.74 \pm 0.09$ & $0.82 \pm 0.25$ & $0.95 \pm 0.26$ & $1.23 \pm 0.34$ & $2.32 \pm 0.77$ \\
\hline HBL-100 & $1.22 \pm 0.44$ & $1.76 \pm 0.59$ & $2.82 \pm 1.51$ & $1.44 \pm 0.26$ & $1.93 \pm 0.51$ & $3.18 \pm 1.23$ \\
\hline HMEC-1 & $1.34 \pm 0.21$ & $1.06 \pm 0.14$ & $0.64 \pm 0.04$ & $1.08 \pm 0.1$ & $0.98 \pm 0.07$ & $0.67 \pm 0.05$ \\
\hline BMH29L & $0.83 \pm 0.08$ & $0.64 \pm 0.08$ & $0.40 \pm 0.03$ & $0.85 \pm 0.21$ & $0.79 \pm 0.2$ & $0.81 \pm 0.17$ \\
\hline A549 & $0.92 \pm 0.32$ & $1.56 \pm 0.47$ & $1.93 \pm 0.61$ & $0.73 \pm 0.04$ & $1.12 \pm 0.41$ & $1.5 \pm 0.63$ \\
\hline SK-N-SH & $1.10 \pm 0.43$ & $1.39 \pm 0.05$ & $4.58 \pm 1.7$ & $0.52 \pm 0.06$ & $0.71 \pm 0.08$ & $0.70 \pm 0.08$ \\
\hline U87 & $6.57 \pm 3.39$ & $8.18 \pm 2.02$ & $6.6 \pm 2.21$ & $3.67 \pm 1.31$ & $2.45 \pm 0.68$ & $1.69 \pm 0.91$ \\
\hline
\end{tabular}


3 different breast cancer cell lines. In MCF-7 cells, the combination of propranolol and paclitaxel resulted in a slight antagonism at $1 \mathrm{nM}$ paclitaxel but it became highly synergistic with increasing paclitaxel concentrations. In contrast, this drug combination led to a sub-additive effect at all tested concentrations in MDA-MB-231 cells and changed from additivity to antagonism with increasing paclitaxel concentrations in SKBR3 cells. In BMH29L cells, the combination of propranolol with paclitaxel led to a synergistic effect irrespectively of the dose of paclitaxel used whereas in HMEC-1 cells, this combination was sub-additive, additive and synergistic at 5, 10 and 25nM paclitaxel, respectively. Finally, mixed results were also obtained with the other cancer cell lines (Table 1). In A549, the interaction between paclitaxel and propranolol changed from synergism to antagonism with increasing paclitaxel concentration whereas this drug combination was synergistic and antagonistic at all tested drug concentrations in SK-N-SH and U87 cells, respectively. Propranolol thus appeared to modulate the anti-proliferative effects of chemotherapy in vitro in a cell type-specific and dose-dependent manner.

A

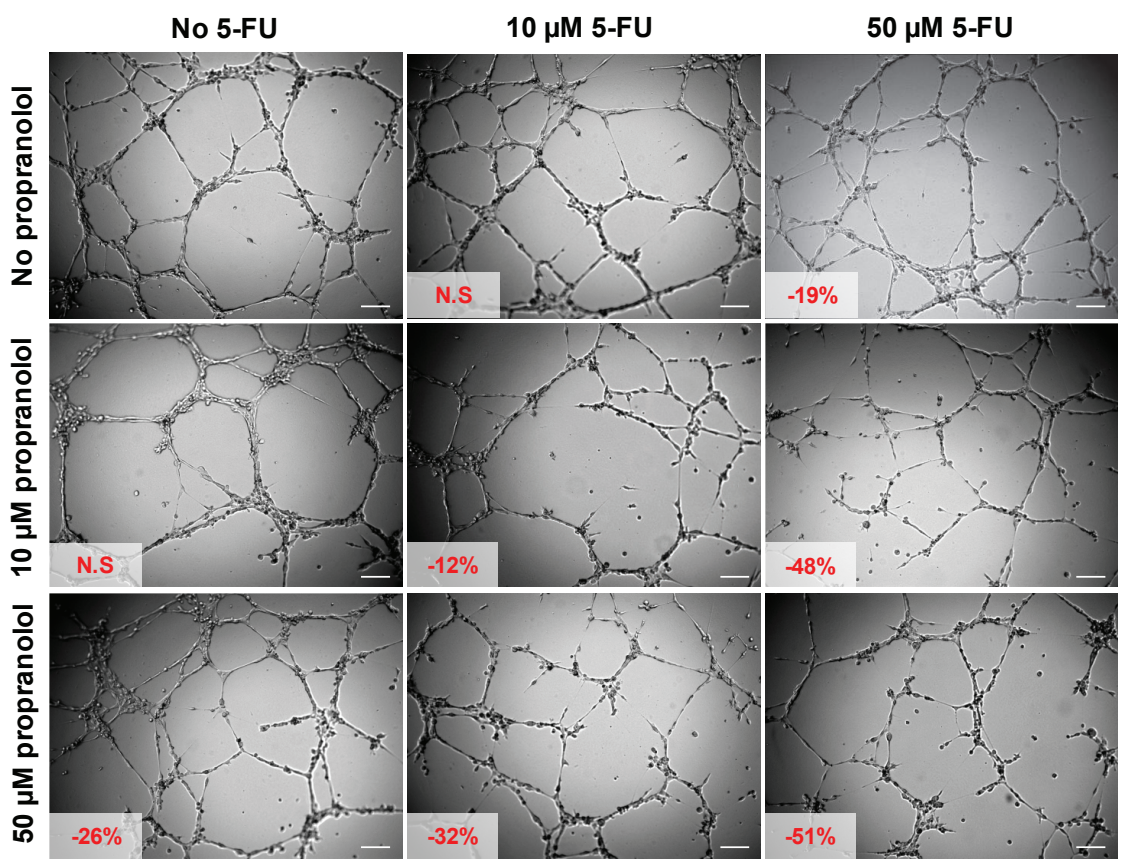

B

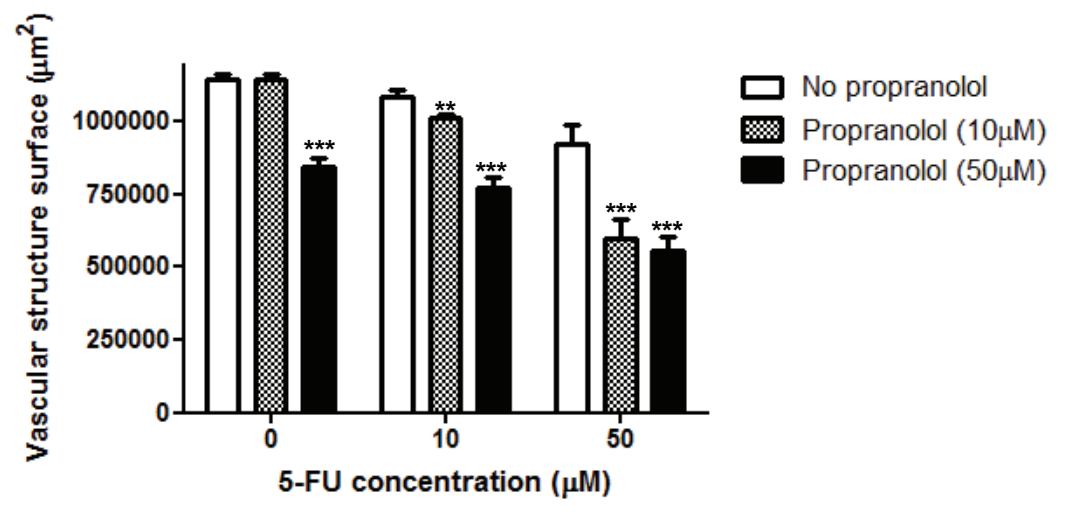

Figure 4: In vitro drug combination study of propranolol and 5-fluorouracil on angiogenesis. A) Representative photographs of HMEC-1 cells in Matrigel ${ }^{\mathrm{TM}}$ assay. Cells were treated 20 min after seeding on Matrigel ${ }^{\mathrm{TM}}$ with a range of 5-fluorouracil concentrations $(0$, left panel; $10 \mu \mathrm{M}$, middle panel and $50 \mu \mathrm{M}$, right panel) in absence (top panel) or presence of propranolol $(10 \mu \mathrm{M}$, middle panel and $50 \mu \mathrm{M}$, bottom panel) and photographs were taken after 8h drug incubation. Vascular structures were imaged on a Zeiss Axiovert 200M using a $5 \mathrm{X}$ objective. Inset, $\%$ of inhibition as compared to untreated control cells (N.S = not statistically significant); Scale bar, $200 \mu \mathrm{m}$. B) Histogram representation of the anti-angiogenic effects of 5-fluorouracil in combination with propranolol. Columns, means of at least four individual experiments; bars, SE. Statistical analysis by ANOVA, combination vs 5-FU alone: ** $\mathrm{p}<0.01 ; * * * \mathrm{p}<0.001$. 


\section{Propranolol potentiates the anti-angiogenic effects of chemotherapy in vitro}

To further explore the potential of propranolol to enhance the anti-cancer effects of chemotherapy, drug combination studies using Matrigel ${ }^{\mathrm{TM}}$ assay were performed. As shown in Figure 4, propranolol was able to potentiate the anti-angiogenic effects induced by $5-\mathrm{FU}$. While incubation with $10 \mu \mathrm{M}$ of either drug alone did not significantly affect the capacity of HMEC-1 cells to form vascular structures, the combination of both drugs at this concentration resulted in a small but significant inhibition of angiogenesis $(-12 \%$; $\mathrm{p}<0.01)$ (Figure $4 \mathrm{~A})$. The presence of $10 \mu \mathrm{M}$ propranolol further increased the inhibition of angiogenesis induced by $50 \mu \mathrm{M} 5$-FU from 19 to $48 \%(p<0.001)$. The effect however did not dramatically increase when higher concentrations of propranolol were used.

The combination of propranolol and paclitaxel appeared to be even more potent at inhibiting angiogenesis (Figure 5). In the absence of propranolol, 10 and 50 $\mathrm{nM}$ paclitaxel inhibited vascular structure formation by 44 and $71 \%$, respectively whereas in the presence of $10 \mu \mathrm{M}$ propranolol this increased to 76 and $92 \%$ inhibition, respectively $(\mathrm{p}<0.05)$. Similar results were

A
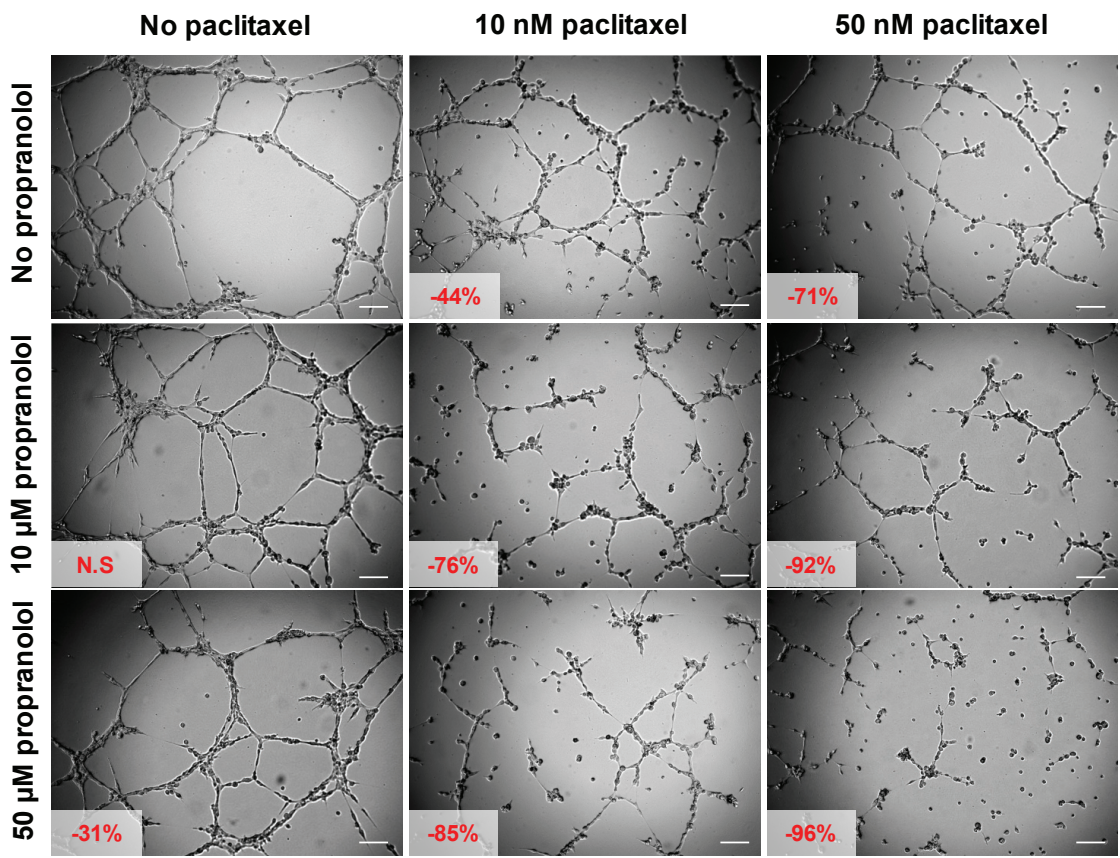

B

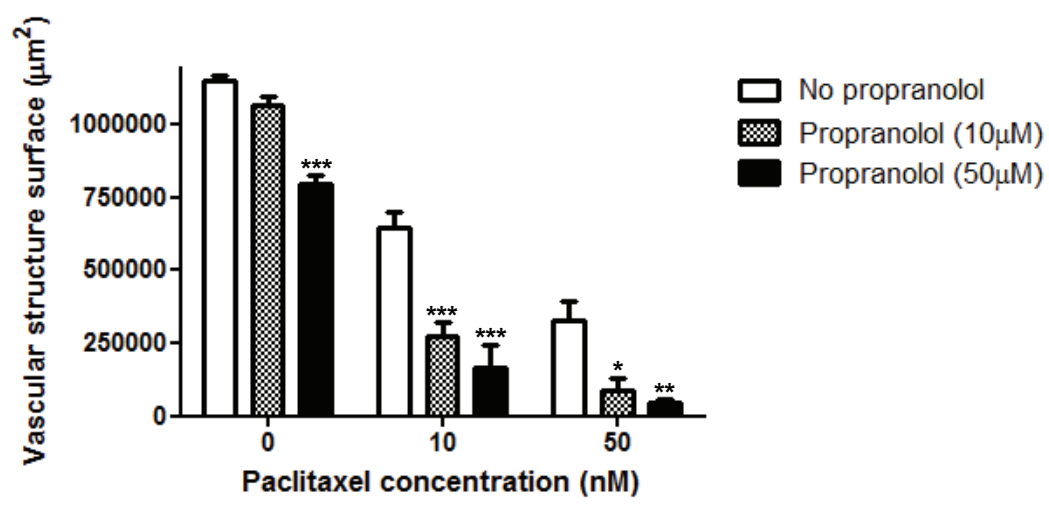

Figure 5: In vitro drug combination study of propranolol and paclitaxel on angiogenesis. A) Representative photographs of HMEC-1 cells in Matrige ${ }^{\mathrm{TM}}$ assay. Cells were treated 20 min after seeding on Matrigel ${ }^{\mathrm{TM}}$ with a range of paclitaxel concentrations $(0$, left panel; $10 \mathrm{nM}$, middle panel and $50 \mathrm{nM}$, right panel) in absence (top panel) or presence of propranolol (10 $\mu \mathrm{M}$, middle panel and 50 $\mu \mathrm{M}$, bottom panel) and photographs were taken after $8 \mathrm{~h}$ drug incubation. Vascular structures were imaged on a Zeiss Axiovert 200M using a $5 \mathrm{X}$ objective. Inset, \% of inhibition as compared to untreated control cells (N.S = not statistically significant); Scale bar, $200 \mu \mathrm{m}$. B) Histogram representation of the anti-angiogenic effects of paclitaxel in combination with propranolol. Columns, means of at least four individual experiments; bars, SE. Statistical analysis by ANOVA, combination vs paclitaxel alone: ${ }^{*} \mathrm{p}<0.05 ; * * \mathrm{p}<0.01 ; * * * \mathrm{p}<0.001$. 
obtained with BMH29L cells (data not shown). Timelapse videomicroscopy experiments further confirmed the increase in the anti-angiogenic effects of paclitaxel when used in combination with propranolol (supplementary videos 1-4). As compared to treatment with either drug alone, treatment with the combination resulted in incomplete morphological differentiation of endothelial cells into vascular structures, followed by regression of the few structures formed (supplementary video 4). Collectively these results demonstrate that propranolol can significantly potentiate the anti-angiogenic effects of chemotherapeutic drugs in vitro.

\section{Propranololincreases the efficacy of chemotherapy in a mouse orthotopic model of human triple- negative breast cancer}

To investigate the effect of combining propranolol with chemotherapy on tumor growth and survival in vivo, a mouse orthotopic model of human triple-negative breast cancer was used and the combination of propranolol and paclitaxel was evaluated. Treatment consisted of i.p injections of paclitaxel alone $(20 \mathrm{mg} / \mathrm{kg}, 3$ days a week for 3 weeks), propranolol alone ( $10 \mathrm{mg} / \mathrm{kg}, 5$ days a week for 5 weeks) or the combination of both drugs. All three treatments were well tolerated as evidenced by an absence of weight loss or change in animal well-being as compared with vehicle-only treated mice (data not shown). Weekly bioluminescence measurements showed that propranolol alone did not significantly delay tumor growth, whereas treatment with paclitaxel alone or in combination with propranolol considerably inhibited tumor progression (Figure 6A-B). The addition of propranolol to paclitaxel did not significantly increase the very potent anti-tumor effects induced by paclitaxel alone (Figure 6A-B and supplementary Figure 5). It did however induce significant survival benefits as compared to paclitaxel alone (Figure $6 \mathrm{C}$ and Table 2). Median survival was thus increased from 70 days in animals treated with paclitaxel alone to 125 days in animals receiving the combination of propranolol and paclitaxel. Furthermore, at study completion (150 days after start of treatment), $12.5 \%$ (1/8) and 25\% (2/8) of mice were tumor-free in the cohorts of animals receiving paclitaxel alone and the combination of propranolol and paclitaxel, respectively.

Similar results were obtained when combining propranolol and 5-FU in vivo (supplementary Figure 6 and Table 2). The addition of propranolol to 5-FU did not significantly increase the anti-tumor effects induced by 5 -FU alone, except at week 4 of treatment $(\mathrm{p}<0.05)$. However, this combination appeared to be the most effective treatment regimen in terms of survival benefits. Indeed, it led to a substantial increase in median survival from 44 days for both vehicle-treated and propranololtreated mice and 47 days for mice treated with 5-FU alone to 56 days for mice treated with the combination. Our results thus demonstrate that propranolol can enhance the efficacy of chemotherapy in a mouse orthotopic model of human triple-negative breast cancer.

\section{DISCUSSION}

Accumulating clinical evidence suggests that beta-adrenergic receptor antagonists and propranolol in particular may lead to increased survival and decreased recurrence in breast cancer patients [30-32]. Here, we provide the first evidence that propranolol can increase the efficacy of chemotherapy, either through direct effects on tumor angiogenesis and/or by potentiating the antiangiogenic and anti-tumor effects of chemotherapeutic drugs.

Our study first demonstrated that propranolol has relatively modest anti-proliferative properties in vitro against a panel of 9 human cell lines. High concentrations of propranolol were required to significantly inhibit cell proliferation, with $\mathrm{IC}_{50}$ values ranging from $100 \mu \mathrm{M}$ to $>250$ $\mu \mathrm{M}$ across the panel of cell lines. Early pharmacokinetics studies revealed that clinically relevant concentrations of propranolol are in the low $\mu \mathrm{M}$ range $[35,36]$, thus suggesting that propranolol alone is not likely to inhibit cell proliferation in vivo. The sensitivity to propranolol was cell type specific but did not depend on the tissue of origin, since all 4 cell lines of breast tissue origin displayed different levels of sensitivity. Interestingly, MCF-7 breast cancer cells were twice as much sensitive to propranolol than MDA-MB-231 cells, although the former have been reported to express low levels of $\beta$-ARs as compared to the latter [37]. This suggests that the level of $\beta$-AR expression may not directly influence cell sensitivity to the antiproliferative effect of propranolol. In contrast with its modest effects on cell proliferation, propranolol was able to significantly inhibit angiogenesis in vitro at relatively low concentrations (from 10 and $20 \mu \mathrm{M}$ in BMH29L and HMEC-1 cells, respectively). These results were consistent with those previously reported with other types of vascular endothelial cells (i.e. HUVEC and HMVEC) [18] and confirmed the potent anti-angiogenic activity of propranolol. The current study further showed that unlike microtubule-depolymerizing agents [38], propranolol has almost no vascular-disrupting activity in addition to its anti-angiogenic properties. This result indicates that the anti-vascular properties of propranolol reported in various pre-clinical and clinical studies $[5,26,27]$ are mostly due to the inhibition of new capillary tube formation rather than the disruption of pre-existing vessels.

Our in vitro combination studies revealed that low concentrations of propranolol can modulate the anti-proliferative effects of chemotherapeutic drugs in vitro in a cell type-specific and dose-dependent manner. Interestingly, human breast carcinoma and vascular endothelial cell lines were among the most responsive 
Table 2: Median survival of breast tumor-bearing mice. Median survival and log-rank test values as determined from the KaplanMeier survival curves. Time is expressed in days since start of treatment.

\begin{tabular}{|l|c|c|c|c|}
\hline & \multicolumn{2}{|c|}{ Propranolol and Paclitaxel } & \multicolumn{2}{c|}{ Propranolol and 5-Fluorouracil } \\
\hline & Median survival (d) & Log rank test & Median survival (d) & Log rank test \\
\hline Control & $\mathbf{4 7}$ & - & $\mathbf{4 4}$ & - \\
\hline Propranolol & $\mathbf{4 4}$ & 0.916 & $\mathbf{4 4}$ & 0.18 \\
\hline Chemotherapy & $\mathbf{7 0}$ & 0.0003 & $\mathbf{4 7}$ & 0.026 \\
\hline Combination & $\mathbf{1 2 5}$ & 0.0005 & $\mathbf{5 6}$ & 0.0005 \\
\hline
\end{tabular}

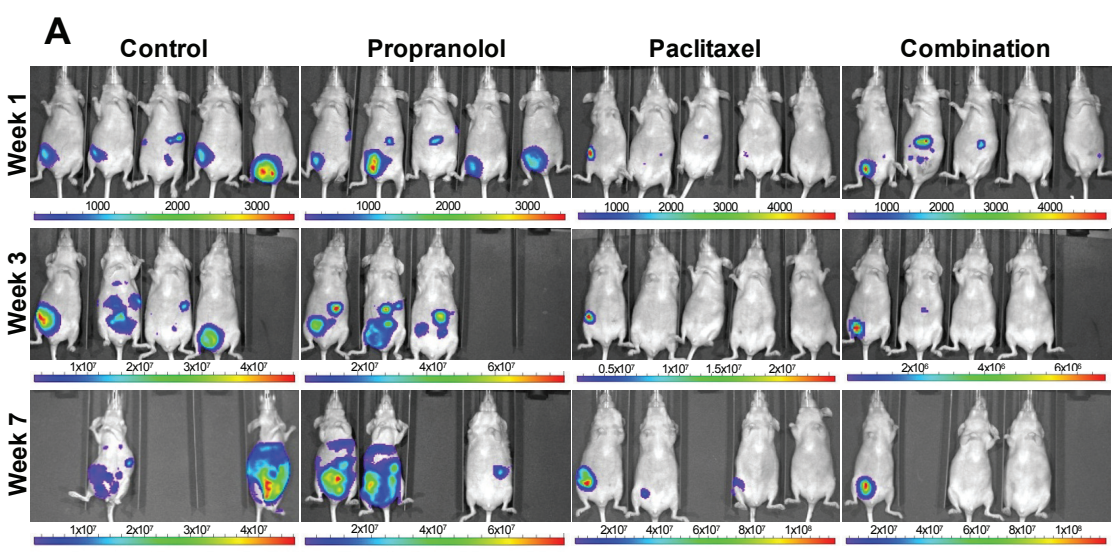

B

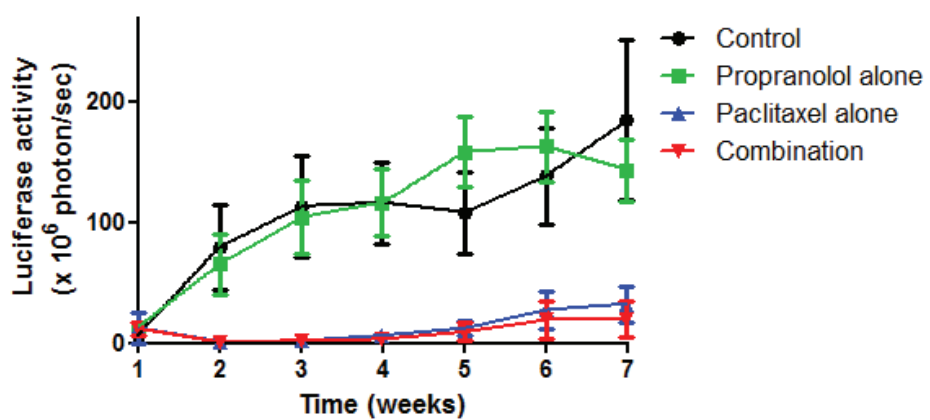

C

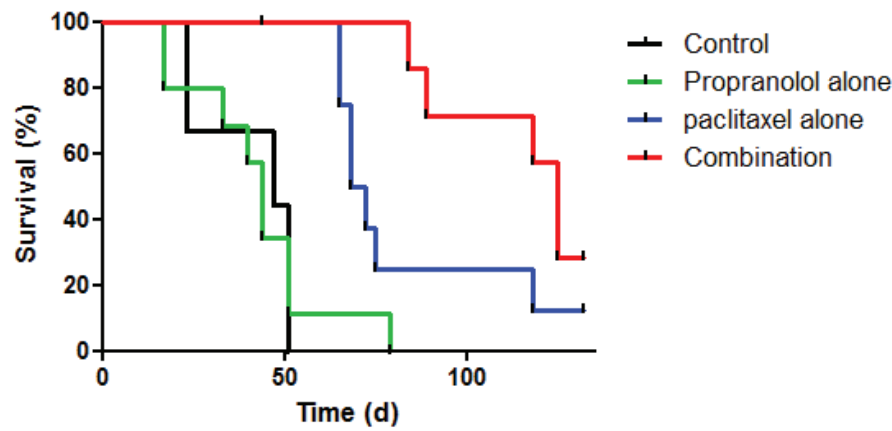

Figure 6: In vitro drug combination study of propranolol and paclitaxel. NMRI nude mice were injected with luciferaseexpressing MDA-MB-231 cells into the mammary fat pad and randomized into 4 groups following confirmation of engraftment. Treatment was initiated 3 weeks after tumor cell injection and consisted of i.p injection of saline 5 days a week for up to 5 weeks, $10 \mathrm{mg} / \mathrm{kg}$ propranolol alone 5 days a week for 5 weeks, $20 \mathrm{mg} / \mathrm{kg}$ paclitaxel alone 3 days a week for 3 weeks or the combination of propranolol and paclitaxel. A) Representative pictures of bioluminescence measurements performed 1 week (top panel), 3 weeks (middle panel) and 7 weeks (bottom panel) after treatment was initiated. The color scale indicates the signal intensity, which is directly proportional to the number of tumor cells. Pictures taken at 6 different wavelengths (i.e.,580 to $630 \mathrm{~nm}$ ) were next combined for 3D reconstruction and tumor size evaluation. B) Quantitative analysis of tumor growth by weekly measurements of luciferase activity in mice treated with saline only (black; $\mathrm{n}=6)$, propranolol alone (green; $\mathrm{n}=10)$, paclitaxel alone (blue; $\mathrm{n}=8)$ and the combination of propranolol and paclitaxel $($ red $; \mathrm{n}=8)$. Points, average luciferase activity; bars, SE; time is expressed in weeks since start of treatment. C) Kaplan-Meier survival curve; time is expressed in days since start of treatment. 
to the combination of propranolol and chemotherapy. Consistent with our results, a recent study has shown that the combination of radiotherapy with propranolol in gastric cancer cells in vitro led to an increase in radiotherapy-induced apoptosis [39]. Elsewhere, $\beta$-AR agonists such as epinephrine have been previously reported to induce resistance to paclitaxel in MCF7 breast cancer cells [40] and to 5-FU in HT-29 colon cancer cells [41] through up-regulation of the $A B C B 1$ gene. However, these two studies also showed that propranolol was unable to prevent epinephrine-induced overexpression of $A B C B 1$ and its product $\mathrm{P}$-glycoprotein. This not only suggests that the potentiation of the antiproliferative effects of 5-FU and paclitaxel by propranolol reported in the current study is independent from $A B C B 1$ up-regulation but also reveals that additional mechanisms, yet to be discovered, are involved in the regulation of drug sensitivity by $\beta$-AR signaling. Based on the high sensitivity of vascular endothelial cells to propranolol, we hypothesized that propranolol may also potentiate the antiangiogenic effects of chemotherapeutic drugs. Our finding that combining low concentrations of propranolol with 5-FU or paclitaxel significantly increases angiogenesis inhibition in vitro, demonstrates for the first time that propranolol can potentiate the anti-angiogenic properties of chemotherapeutic drugs through direct effects on endothelial cells. Additional experiments are currently underway to unravel the mechanisms involved in the synergism between propranolol and chemotherapeutic drugs against cell proliferation and angiogenesis in vitro. A number of candidates are being considered. These include cAMP-protein kinase A (PKA) and Src kinase signaling pathways, which are both involved in the adrenergic regulation of cancer cell proliferation and invasion, as well as the inhibition of VEGF receptor-2 tyrosine phosphorylation and MMP-9 secretion, which have been shown to mediate the anti-angiogenic effects of propranolol in vitro [17, 18, 42, 43].

Triple-negative breast cancer is estimated to affect more than 170,000 women worldwide each year and associated with a poor prognosis [44]. Effective therapeutic options are very limited but $\beta$-AR antagonists have been recently found to be particularly beneficial in triple-negative breast cancer patients [32]. The potentiation of the anti-proliferative and anti-angiogenic effects of chemotherapeutic drugs in vitro demonstrated in the current study provides two potential mechanisms by which propranolol may be able to increase the antitumor efficacy of chemotherapy in vivo. Previous studies have found that propranolol could inhibit the development of stress-induced metastasis in preclinical models of both ovarian and breast cancer but it only affected primary tumor growth in the ovarian cancer model $[26,27]$. Here we found that propranolol alone induced only minor and transient anti-tumor effects in a mouse orthotopic model of breast cancer and it did not lead to survival benefits.
This result, together with those previously reported in the literature, suggest that the anti-tumor effects of propranolol are most likely to occur in small disseminated tumors but not in larger, bulky tumors, which is consistent with the potent anti-angiogenic but weak vascular-disrupting properties of propranolol reported here. Nevertheless, our study further showed that, in absence of chronic stress, propranolol can enhance the efficacy of chemotherapy in vivo. Although the difference did not reach statistical significance, there was a clear trend towards a more potent anti-tumor effect when propranolol was combined with chemotherapy, as compared with chemotherapy alone. Furthermore, combining propranolol to chemotherapy resulted in improved survival in two independent in vivo studies. The addition of propranolol thus increased the median survival by $79 \%$ and $19 \%$ as compared to paclitaxel alone and 5-FU alone, respectively.

Collectively, our results indicate that propranolol could potentially be used concomitantly with chemotherapy in breast cancer patients to increase treatment efficacy. The evaluation of such combination therapy in prospective clinical trials is urgently needed, particularly in triple-negative breast cancer patients for whom effective therapeutic options are extremely limited. If successful, this clinical translation could rapidly impact on the treatment of more than 1 million women worldwide affected by breast cancer each year, thus further illustrating the numerous advantages of drug repositioning in terms of time- and cost-saving. Finally, it is also important to note that $\beta$-AR antagonists could also be beneficial in other types of drug-refractory solid tumors and warrants further investigation in clinically-relevant models of both adult and childhood cancers.

\section{MATERIAL AND METHODS}

\section{Reagents}

Propranolol (Sigma-Aldrich, Castle Hill, Australia) was resuspended in water and stock solutions (50 $\mathrm{mM}$ ) were stored at $4^{\circ} \mathrm{C}$. Commercial solutions of 5 -fluorouracil in saline were obtained from La Timone University Hospital of Marseille, France and Hospira Australia (Mulgrave North, Australia) and stored at room temperature. Paclitaxel (Sigma-Aldrich) was resuspended in DMSO and stock solutions $(2 \mathrm{mM})$ were stored at $-20^{\circ} \mathrm{C}$

\section{Cell culture}

The breast cancer cell line MCF-7 and glioblastoma cell line U87 were maintained in DMEM medium (Invitrogen, Mount Waverley, Australia), the breast cancer cell line MDA-MB-231, non-small cell lung cancer cell 
line A549 and neuroblastoma cell line SK-N-SH were maintained in RPMI-1640 medium (Invitrogen), the breast cancer cell line SKBR3 was maintained in McCoy'5A medium (Invitrogen) and the breast epithelial cell line HBL-100 was maintained in MEM (Invitrogen). All these culture media were supplemented with 10\% Fetal Calf Serum (FCS), 2 mM L-glutamine and 1\% penicillin streptomycin. The microvascular endothelial cell line HMEC-1 was grown on $0.1 \%$ gelatin-coated flasks using MCDB-131 medium (Invitrogen) containing 10\% FCS, 2 $\mathrm{mM}$ L-glutamine, $1 \%$ penicillin and streptomycin, $1 \mu \mathrm{g} /$ $\mathrm{mL}$ hydrocortisone and $10 \mathrm{ng} / \mathrm{mL}$ epithelial growth factor (BioScientific, Gymea, Australia). BMH29L cells are bone marrow derived endothelial cells that were immortalized by ectopic expression of human telomerase reverse transcriptase [45]. They were kindly provided by Dr Karen MacKenzie (Children's Cancer Institute Australia) and grown on $0.1 \%$ gelatin-coated flasks using Medium 199 (Invitrogen) containing 20\% FCS, 5\% AB-only male human serum (Sigma-Aldrich), 1\% penicillin and streptomycin, $1 \%$ heparin, $5 \mathrm{ng} / \mathrm{mL}$ recombinant human $\mathrm{FGF}_{\beta}$ (fibroblast growth factor $\beta$; Sigma-Aldrich) and $20 \mu \mathrm{g} / \mathrm{mL}$ Endothelial Cell Growth Factor (Roche, Dee Why, Australia). All cell lines were routinely maintained in culture at $37^{\circ} \mathrm{C}$ and $5 \% \mathrm{CO}_{2}$ and regularly screened to ensure the absence of mycoplasma contamination.

\section{Growth inhibition assay}

Growth inhibition assays were performed using either Alamar blue (for MCF-7, MDA-MB-231, HMEC1 and BMH29L cells) or MTT (for SKBR3, HBL-100, A549, SK-N-SH and U87), as previously described [46, 47]. For all cell lines, the number of cells seeded (from 1,500 to 10,000 cells per well, depending on the cell line) in 96-well plates was first optimized to ensure sustained exponential growth for 4-6 days. For all cell lines (with the exception of SK-N-SH cells, which were allowed to adhere for $72 \mathrm{~h}$ before treatment was initiated), cells were treated $24 \mathrm{~h}$ after seeding with a range of concentrations of i) propranolol alone ( $1 \times 10^{-7}$ to $\left.1 \times 10^{-4} \mathrm{M}\right)$, ii) chemotherapeutic drugs alone $\left(1 \times 10^{-8}\right.$ to $5 \times 10^{-4} \mathrm{M}$ and 1 x $10^{-11}$ to $1 \times 10^{-7} \mathrm{M}$ for 5 -FU and paclitaxel, respectively) or iii) chemotherapeutic drugs in combination with propranolol at the lowest effective concentration $\left(\mathrm{IC}_{15}\right)$. After $72 \mathrm{~h}$ drug incubation, metabolic activity was detected by addition of Alamar blue or MTT followed by spectrophotometric analysis. Cell proliferation was determined and expressed as a percentage of untreated control cells. The determination of $\mathrm{IC}_{50}$ values was performed using GraphPad Prism 4 software (GraphPad Software Inc, La Jolla, CA). Combination index (CI) values were calculated for all tested drug concentrations according to the Chou and Talalay method $[33,34]$ using the following equation:

where (D) $)_{1}$ and (D) $)_{2}$ represent the dose of agent 1 and
2 used in combination to induce $\mathrm{X} \%$ growth inhibition, and $\left(D_{X}\right)_{1}$ and $\left(D_{X}\right)_{2}$ represent the dose of agent 1 and 2 required to reach $\mathrm{X} \%$ growth inhibition when used alone. The CI theorem then provides quantitative definition for additive effects $(\mathrm{CI}=1)$, synergisms $(\mathrm{CI}<1)$ and antagonisms $(\mathrm{CI}>1)$ in drug combinations.

\section{In vitro Matrigel $^{\mathrm{TM}}$ assay}

The Matrigel ${ }^{\mathrm{TM}}$ (BD Biosciences, North Ryde, Australia) assay was used to determine the anti-angiogenic and vascular-disrupting properties of propranolol alone or in combination with chemotherapeutic agents, as previously described [38]. Briefly, 24-well plates were coated at $4^{\circ} \mathrm{C}$ with $270 \mu \mathrm{L}$ of a Matrigel $^{\mathrm{TM}}$ solution $(1: 1$ dilution in cell culture medium), which was then allowed to solidify for $1 \mathrm{~h}$ at $37^{\circ} \mathrm{C}$ before cell seeding. For the anti-angiogenesis assay, endothelial cells were treated with different drug solutions $20 \mathrm{~min}$ after seeding on Matrigel $^{\mathrm{TM}}$ and photographs were taken after $8 \mathrm{~h}$ drug incubation using the 5X objective of an Axiovert 200M fluorescent microscope coupled to an AxioCamMR3 camera driven by the AxioVision 4.7 software (Carl Zeiss, North Ryde, Australia). For the vascular-disruption assay, endothelial cells were first allowed to undergo morphogenesis and form capillary-like structures for $6 \mathrm{~h}$ before drug treatment was initiated. Photographs were then taken using the same microscope device after $2 \mathrm{~h}$ drug incubation. The anti-angiogenic and vasculardisrupting activities of the compounds were then quantitatively evaluated by measuring the total surface area of capillary tubes formed in at least 10 view fields per well using AxioVision 4.7 software. Time-lapse

$$
C I=\frac{(D)_{1}}{\left(D_{X}\right)_{1}}+\frac{(D)_{2}}{\left(D_{X}\right)_{2}}
$$

videomicroscopy was also employed to further evaluate the effects of propranolol on the anti-angiogenic activity of chemotherapeutic agents, as previously described [38]. Cells were constantly maintained at $37^{\circ} \mathrm{C}$ and $5 \% \mathrm{CO}_{2}$ and photographs were taken every $5 \mathrm{~min}$ from the beginning of drug treatment and for $9 \mathrm{~h}$.

\section{Orthotopic breast cancer model}

To evaluate the effect of combining propranolol with chemotherapy on tumor growth and survival, 7 weeksold NMRI nude mice were injected into the mammary fat pad with 50,000 MDA-MB-231-luc-D3H2LN human breast cancer cells expressing firefly luciferase (Caliper Life Science, Villepinte, France) resuspended in $50 \mu \mathrm{L}$ of a $30 \%$ Matrigel $^{\mathrm{TM}}$ solution. Mice were randomized into 4 different groups 18 days after tumor cell injection following confirmation of engraftment. Treatment was 
initiated 3 weeks after injection and consisted of i.p injections of i) saline ( 5 days a week for up to 5 weeks), ii) paclitaxel alone $(20 \mathrm{mg} / \mathrm{kg}, 3$ days a week for 3 weeks), iii) propranolol alone $(10 \mathrm{mg} / \mathrm{kg}, 5$ days a week for 5 weeks) or iv) the combination of paclitaxel and propranolol following the same administration schedule. Tumor growth was monitored by weekly bioluminescence measurements using the Spectrum IVIS system (Caliper Life Science, Villepinte, France). Briefly, light expressed as photon/sec was measured 15 minutes after i.p injection of $200 \mathrm{mg} / \mathrm{kg}$ Luciferine (Caliper Life Science, Villepinte, France), a time-lag ensuring the signal to reach a plateau. After acquisition, signals were converted into 3D pictures using the Living Image 4.2 software (Caliper Life Science, Villepinte, France). Mice were sacrificed when tumor size reached $5,000 \mathrm{~mm}^{3}$ (as determined using a vernier caliper and the standard formula tumor volume $=$ (thickness $\mathrm{x}$ length $\mathrm{x}$ width) $\mathrm{x} \pi / 6$ ) or when signs of morbidity became apparent (e.g., ataxia, signs of pain or distress, loss of $>15 \%$ of initial weight, loss of mobility due to tumor growth).

The combination of propranolol and 5-FU was also evaluated using the same orthotopic model of triple-negative breast cancer with slight modifications. Briefly, 7 weeks-old NMRI nude mice were injected into the mammary fat pad with 10,000 MDA-MB-231luc-D3H2LN cells in absence of Matrigel ${ }^{\mathrm{TM}}$. Mice were randomized into 4 different groups 7 days after tumor cell injection following confirmation of engraftment. Treatment was initiated 2 weeks after injection and consisted of i.p injections of i) saline (5 days a week for up to 8 weeks), ii) 5 -FU alone $(30 \mathrm{mg} / \mathrm{kg}, 3$ days a week for 5 weeks), iii) propranolol alone $(10 \mathrm{mg} / \mathrm{kg}, 5$ days a week for up to 8 weeks) or iv) the combination of 5-FU and propranolol following the same administration schedule. Tumor growth was monitored by weekly bioluminescence measurement using the same protocol and device described above. Mice were sacrificed when tumor size reached $5,000 \mathrm{~mm}^{3}$ or when signs of morbidity became apparent.

\section{Statistical analysis}

All in vitro experiments were performed at least in triplicate and statistical significance was determined using two-sided student's t test and one-way Anova was used for multiple comparisons. For in vivo studies, the log rank test was used to compare median survival in the different treatment groups. All statistical analyses were performed using GraphPad Prism 4 (GraphPad Software, Inc).

\section{ACKNOWLEDGMENTS}

This work was supported by the Children's Cancer Institute Australia for Medical Research, which is affiliated with the University of New South Wales and Sydney Children's Hospital. Funding was provided by the Cancer Institute New South Wales (EP; 07/ECF/121), the Balnaves Foundation (EP), the University of New South Wales (EP), Gefluc Marseille-Provence (JC), National Health \& Medical Research Senior Research Fellowship (MK), "LN la vie" (NA) and RéSOP (NA). The authors would like to thank Dr Karen MacKenzie (Children's Cancer Institute Australia) for providing the BMH29L bone marrow-derived vascular endothelial cells as well as Dr Bertrand Pourroy (La Timone University Hospital of Marseille, France) for supplying hospitalgrade propranolol, 5-FU and paclitaxel solutions for in vivo studies.

This work was in part presented at the $102^{\text {nd }}$ Annual Meeting of the American Association of Cancer Research, April $2^{\text {nd }}-6^{\text {th }} 2011$, Orlando FL, USA.

\section{SUPPLEMENTARY VIDEOS}

Videos 1-4: In vitro angiogenesis assay by timelapse videomicroscopy. Representative time-lapse videomicroscopy of HMEC-1 cells on Matrigel ${ }^{\mathrm{TM}}$. Cells were seeded on Matrigel ${ }^{\mathrm{TM}}$ either in the absence of drug (video 1 ) or in the presence of $10 \mu \mathrm{M}$ propranolol (video 2), $10 \mathrm{nM}$ paclitaxel (video 3) or a combination of $10 \mu \mathrm{M}$ propranolol and $10 \mathrm{nM}$ paclitaxel (video 4). Photographs were taken every $5 \mathrm{~min}$ for $9 \mathrm{~h}$, using the $5 \mathrm{X}$ objective of an Axiovert 200M fluorescent microscope coupled to an AxioCamMR3 camera driven by the AxioVision 4.7 software (Carl Zeiss). The videos together with the supplementary figures $5 \& 6$ can be found online at www. impactjournals.com/oncotarget

\section{REFERENCES}

1. Yap TA, Sandhu SK, Workman P, de Bono JS. Envisioning the future of early anticancer drug development. Nat Rev Cancer. 2010; 10:514-523.

2. Ashburn TT, Thor KB. Drug repositioning: identifying and developing new uses for existing drugs. Nat Rev Drug Discov. 2004; 3:673-683.

3. O'Connor KA, Roth BL. Finding new tricks for old drugs: an efficient route for public-sector drug discovery. Nat Rev Drug Discov. 2005; 4:1005-1014.

4. Tobinick EL. The value of drug repositioning in the current pharmaceutical market. Drug News Perspect. 2009; 22:119125.

5. Leaute-Labreze C, Dumas de la Roque E, Hubiche T, Boralevi F, Thambo JB, Taieb A. Propranolol for severe hemangiomas of infancy. N Engl J Med. 2008; 358:26492651.

6. Zimmermann AP, Wiegand S, Werner JA, Eivazi B. Propranolol therapy for infantile haemangiomas: review of the literature. Int J Pediatr Otorhinolaryngol. 2010; 74:338- 
342.

7. Schuller HM, Cole B. Regulation of cell proliferation by beta-adrenergic receptors in a human lung adenocarcinoma cell line. Carcinogenesis. 1989; 10:1753-1755.

8. Park PG, Merryman J, Orloff M, Schuller HM. Betaadrenergic mitogenic signal transduction in peripheral lung adenocarcinoma: implications for individuals with preexisting chronic lung disease. Cancer Res. 1995; 55:3504-3508.

9. Masur K, Niggemann B, Zanker KS, Entschladen F. Norepinephrine-induced migration of SW 480 colon carcinoma cells is inhibited by beta-blockers. Cancer Res. $2001 ; 61: 2866-2869$

10. Drell TLt, Joseph J, Lang K, Niggemann B, Zaenker KS, Entschladen F. Effects of neurotransmitters on the chemokinesis and chemotaxis of MDA-MB-468 human breast carcinoma cells. Breast Cancer Res Treat. 2003; 80:63-70.

11. Yang EV, Sood AK, Chen M, Li Y, Eubank TD, Marsh CB, Jewell S, Flavahan NA, Morrison C, Yeh PE, Lemeshow $\mathrm{S}$, Glaser R. Norepinephrine up-regulates the expression of vascular endothelial growth factor, matrix metalloproteinase (MMP)-2, and MMP-9 in nasopharyngeal carcinoma tumor cells. Cancer Res. 2006; 66:10357-10364.

12. Sood AK, Bhatty R, Kamat AA, Landen CN, Han L, Thaker PH, Li Y, Gershenson DM, Lutgendorf S, Cole SW. Stress hormone-mediated invasion of ovarian cancer cells. Clin Cancer Res. 2006; 12:369-375.

13. Zhang $\mathrm{D}, \mathrm{Ma} \mathrm{Q}$, Shen $\mathrm{S}, \mathrm{Hu} \mathrm{H}$. Inhibition of pancreatic cancer cell proliferation by propranolol occurs through apoptosis induction: the study of beta-adrenoceptor antagonist's anticancer effect in pancreatic cancer cell. Pancreas. 2009; 38:94-100.

14. Guo K, Ma Q, Wang L, Hu H, Li J, Zhang D, Zhang M. Norepinephrine-induced invasion by pancreatic cancer cells is inhibited by propranolol. Oncol Rep. 2009; 22:825830 .

15. Zhang D, Ma QY, Hu HT, Zhang M. beta2-adrenergic antagonists suppress pancreatic cancer cell invasion by inhibiting CREB, NFkappaB and AP-1. Cancer Biol Ther. $2010 ; 10: 19-29$

16. Liao X, Che X, Zhao W, Zhang D, Bi T, Wang G. The beta-adrenoceptor antagonist, propranolol, induces human gastric cancer cell apoptosis and cell cycle arrest via inhibiting nuclear factor kappaB signaling. Oncol Rep. 2010; 24:1669-1676.

17. Annabi B, Lachambre MP, Plouffe K, Moumdjian R, Beliveau R. Propranolol adrenergic blockade inhibits human brain endothelial cells tubulogenesis and matrix metalloproteinase-9 secretion. Pharmacol Res. 2009; 60:438-445.

18. Lamy S, Lachambre MP, Lord-Dufour S, Beliveau R. Propranolol suppresses angiogenesis in vitro: inhibition of proliferation, migration, and differentiation of endothelial cells. Vascul Pharmacol. 2010; 53:200-208.

19. Fredriksson JM, Lindquist JM, Bronnikov GE, Nedergaard J. Norepinephrine induces vascular endothelial growth factor gene expression in brown adipocytes through a beta -adrenoreceptor/cAMP/protein kinase A pathway involving Src but independently of Erk1/2. J Biol Chem. 2000; 275:13802-13811.

20. Lutgendorf SK, Cole S, Costanzo E, Bradley S, Coffin J, Jabbari S, Rainwater K, Ritchie JM, Yang M, Sood AK. Stress-related mediators stimulate vascular endothelial growth factor secretion by two ovarian cancer cell lines. Clin Cancer Res. 2003; 9:4514-4521.

21. Nilsson MB, Armaiz-Pena G, Takahashi R, Lin YG, Trevino J, Li Y, Jennings N, Arevalo J, Lutgendorf SK, Gallick GE, Sanguino AM, Lopez-Berestein G, Cole SW, Sood AK. Stress hormones regulate interleukin-6 expression by human ovarian carcinoma cells through a Src-dependent mechanism. J Biol Chem. 2007; 282:2991929926.

22. Hajighasemi F, Hajighasemi S. Effect of propranolol on angiogenic factors in human hematopoietic cell lines in vitro. Iran Biomed J. 2009; 13:223-228.

23. Park SY, Kang JH, Jeong KJ, Lee J, Han JW, Choi WS, Kim YK, Kang J, Park CG, Lee HY. Norepinephrine induces VEGF expression and angiogenesis by a hypoxiainducible factor-1alpha protein-dependent mechanism. Int J Cancer. 2011; 128:2306-2316.

24. Schuller HM, Porter B, Riechert A. Beta-adrenergic modulation of NNK-induced lung carcinogenesis in hamsters. J Cancer Res Clin Oncol. 2000; 126:624-630.

25. Al-Wadei HA, Al-Wadei MH, Schuller HM. Prevention of pancreatic cancer by the beta-blocker propranolol. Anticancer Drugs. 2009; 20:477-482.

26. Thaker PH, Han LY, Kamat AA, Arevalo JM, Takahashi R, Lu C, Jennings NB, Armaiz-Pena G, Bankson JA, Ravoori M, Merritt WM, Lin YG, Mangala LS, Kim TJ, Coleman $\mathrm{RL}$, Landen $\mathrm{CN}$ et al. Chronic stress promotes tumor growth and angiogenesis in a mouse model of ovarian carcinoma. Nat Med. 2006; 12:939-944.

27. Sloan EK, Priceman SJ, Cox BF, Yu S, Pimentel MA, Tangkanangnukul V, Arevalo JM, Morizono K, Karanikolas BD, Wu L, Sood AK, Cole SW. The sympathetic nervous system induces a metastatic switch in primary breast cancer. Cancer Res. 2010; 70:7042-7052.

28. Schuller HM. Beta-adrenergic signaling, a novel target for cancer therapy? Oncotarget. 2010; 1:466-469.

29. Powe DG, Entschladen F. Targeted therapies: Using betablockers to inhibit breast cancer progression. Nat Rev Clin Oncol. 2011; 8:511-512.

30. Powe DG, Voss MJ, Zanker KS, Habashy HO, Green AR, Ellis IO, Entschladen F. Beta-blocker drug therapy reduces secondary cancer formation in breast cancer and improves cancer specific survival. Oncotarget. 2010; 1:628-638.

31. Barron TI, Connolly RM, Sharp L, Bennett K, Visvanathan 
K. Beta blockers and breast cancer mortality: a populationbased study. J Clin Oncol. 2011; 29:2635-2644.

32. Melhem-Bertrandt A, Chavez-Macgregor M, Lei X, Brown EN, Lee RT, Meric-Bernstam F, Sood AK, Conzen SD, Hortobagyi GN, Gonzalez-Angulo AM. Beta-blocker use is associated with improved relapse-free survival in patients with triple-negative breast cancer. J Clin Oncol. 2011; 29:2645-2652.

33. Chou TC, Talalay P. Quantitative analysis of dose-effect relationships: the combined effects of multiple drugs or enzyme inhibitors. Adv Enzyme Regul. 1984; 22:27-55.

34. Chou TC. Drug combination studies and their synergy quantification using the Chou-Talalay method. Cancer Res. 2010; 70:440-446.

35. Wong L, Nation RL, Chiou WL, Mehta PK. Plasma concentrations of propranolol and 4-hydroxypropranolol during chronic oral propranolol therapy. $\mathrm{Br} \mathrm{J}$ Clin Pharmacol. 1979; 8:163-167.

36. Duff HJ, Roden DM, Brorson L, Wood AJ, Dawson AK, Primm RK, Oates JA, Smith RF, Woosley RL. Electrophysiologic actions of high plasma concentrations of propranolol in human subjects. J Am Coll Cardiol. 1983; 2:1134-1140.

37. Madden KS, Szpunar MJ, Brown EB. beta-Adrenergic receptors (beta-AR) regulate VEGF and IL-6 production by divergent pathways in high beta-AR-expressing breast cancer cell lines. Breast Cancer Res Treat. 2011.

38. Pasquier E, Sinnappan S, Munoz MA, Kavallaris M. ENMD-1198, a new analogue of 2-methoxyestradiol, displays both antiangiogenic and vascular-disrupting properties. Mol Cancer Ther. 2010; 9:1408-1418.

39. Liao X, Che X, Zhao W, Zhang D, Long H, Chaudhary P, Li H. Effects of propranolol in combination with radiation on apoptosis and survival of gastric cancer cells in vitro. Radiat Oncol. 2010; 5:98.

40. Su F, Ouyang N, Zhu P, Jia W, Gong C, Ma X, Xu H, Song E. Psychological stress induces chemoresistance in breast cancer by upregulating mdr1. Biochem Biophys Res Commun. 2005; 329:888-897.

41. Yao H, Duan Z, Wang M, Awonuga AO, Rappolee D, Xie Y. Adrenaline induces chemoresistance in HT-29 colon adenocarcinoma cells. Cancer Genet Cytogenet. 2009; 190:81-87.

42. Chakroborty D, Sarkar C, Basu B, Dasgupta PS, Basu S. Catecholamines regulate tumor angiogenesis. Cancer Res. 2009; 69:3727-3730.

43. Storch $\mathrm{CH}$, Hoeger PH. Propranolol for infantile haemangiomas: insights into the molecular mechanisms of action. Br J Dermatol. 2010; 163:269-274.

44. Anders C, Carey LA. Understanding and treating triplenegative breast cancer. Oncology (Williston Park). 2008; 22:1233-1239; discussion 1239-1240, 1243.

45. MacKenzie KL, Franco S, Naiyer AJ, May C, Sadelain M, Rafii S, Moore MA. Multiple stages of malignant transformation of human endothelial cells modelled by co-expression of telomerase reverse transcriptase, SV40 T antigen and oncogenic N-ras. Oncogene. 2002; 21:42004211.

46. Verrills NM, Flemming CL, Liu M, Ivery MT, Cobon GS, Norris MD, Haber M, Kavallaris M. Microtubule alterations and mutations induced by desoxyepothilone B: implications for drug-target interactions. Chem Biol. 2003; 10:597-607.

47. Pasquier E, Carre M, Pourroy B, Camoin L, Rebai O, Briand C, Braguer D. Antiangiogenic activity of paclitaxel is associated with its cytostatic effect, mediated by the initiation but not completion of a mitochondrial apoptotic signaling pathway. Mol Cancer Ther. 2004; 3:1301-1310. 